Albores de

la Conquista

5

Diana Magaloni Kerpel

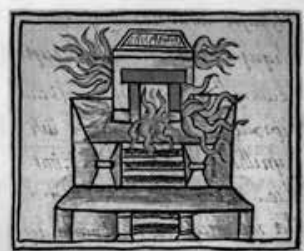

APTES
- Albores de la Conquista

Diana Magaloni Kerpel, 2016

Artes de México y del Mundo/

Secretaría de Cultura, México

\title{
La conquista de México como mito de muerte y renacimiento
}

\author{
GUILLERMO DE LA PEÑA
}

The Conquest of Mexico as a

Myth of Death and Rebirth

Guillermo de LA PeÑA Centro de Investigaciones y Estudios Superiores-Occidente, Guadalajara, Jalisco, México gdelapen@gmail.com

Desacatos 59, enero-abril 2019, pp. 192-195
Para conjurar los efectos de estos aires, en los Altos de Morelos se celebran rituales en los que se emplean piezas de cerámica fabricadas ad hoc (Rojas, 1973).

urante mis trabajos de campo en comunidades de origen nahua en los Altos de Morelos y el Sur de Jalisco, oí mencionar con alguna frecuencia a ciertos personajes que vivían dentro de los cerros y eran sus guardianes. Sus funciones incluían la provisión de lluvia, el mantenimiento de la humedad interna del monte, el cuidado de los bosques y los ojos de agua, y la vigilancia de las entradas al inframundo de los ancestros. Eran descritos como enanitos, con cara de niños traviesos. En el Sur de Jalisco los llamaban duendes, o ruendes, y podían causar, si estaban de mal humor o nomás por travesura, enduendamientos que enfermaban a niños y ancianos, y trastornaban a los borrachos (De la Peña, 2006: 114-116; Robertson, 2002). También adoptaban la forma de aires malignos. ${ }^{1}$ Para evitar sus daños, era necesario rendirles ofrendas, por ejemplo, colocar bebidas alcohólicas o alimentos junto a las lagunillas y manantiales. En Morelos me contaban que, en el pasado remoto, los duendes incluso llegaban a exigir el 
sacrificio de niños, al borde de las fuentes, para que el agua no dejara de brotar (De la Peña, 1980: 44).

En el panteón prehispánico del mundo nahua, estos personajes eran conocidos de manera genérica como tlaloques, compañeros del dios pluvial Tláloc, o con los nombres más específicos de ahuaques o chaneques. Así aparecen en la Historia general de las cosas de la Nueva España, de fray Bernardino de Sahagún (1975: 35), y en otros escritos de la época colonial temprana, por ejemplo, en el inventario de creencias y prácticas paganas que recopiló Hernando Ruiz de Alarcón y el Confesionario de Bartolomé de Alva Ixtlixóchitl (citados en Schwaller, 2014: 50, 58). ${ }^{2}$ Lo sorprendente es que se continúe hablando - $-\mathrm{y}$ aceptando la existencia- de estos duendes traviesos de manera semejante a las descripciones de los siglos XVI y XVII, tanto en Morelos y Jalisco como en otras regiones. En la Sierra de Texcoco se les sigue llamando ahuaques (Lorente, 2006). También es interesante que su culto se inserte sin mayor problema en el calendario del catolicismo popular: en los Altos de Morelos se llevan ofrendas a los montes en la fiesta de san Juan Bautista, que asegura la lluvia y tal vez sea un trasunto de Tláloc; en el Sur de Jalisco se pide permiso a los duendes para recoger el heno con el que se confeccionan los trajes de los danzantes paixtles que participan en las fiestas navideñas.

Me he permitido hacer estas referencias a mis trabajos etnográficos de hace años porque el libro de Diana Magaloni Kerpel ha reavivado mi fascinación por la Historia... de Sahagún, que nos ilumina acerca del surgimiento de una nueva civilización en la que se encuentran, dialogan y conviven las cosmovisiones europeas y mesoamericanas. Este diálogo sigue vigente y se reproduce en nuestros pueblos indígenas, tanto en las zonas urbanas como en las rurales. La persistencia de los tlaloques en la vida cotidiana ha sido posible porque forman parte de un conjunto de representaciones colectivas que moldean la historia de las familias y las comunidades. Esas representaciones se transmiten de manera oral de generación en generación y mediante imágenes de varios tipos: pinturas producidas en las localidades, ilustraciones de libros o periódicos, petroglifos, decoraciones, carros alegóricos, coreografías en danzas y dramaturgias en festivales. El símbolo de Ehécatl/Quetzalcóatl, el dios nahua de los vientos, plasmado en un petroglifo en la Sierra de Manantlán, Jalisco, se asocia a la tradición local que identifica a los lugareños como un grupo "azteca” y legitima la defensa de su territorio. En las antiguas comunidades caxcanes de la periferia de Guadalajara, la Danza de los Tastoanes escenifica la derrota del apóstol Santiago a manos de los "salvajes" y su transformación en una fuerza benéfica. Así, esta danza reinterpreta la historia oficial, refuerza la identidad comunitaria y apoya la lucha por la tierra.

La narrativa de las imágenes ha sido, y es, un elemento distintivo del mundo mesoamericano. En el libro de Magaloni Kerpel, y en sus ilustraciones abundantes y magníficas, se nos recuerda que la civilización nahua encontrada por los conquistadores españoles no carecía de escritura, aunque no tuviera un alfabeto. ${ }^{3}$ La inmensa labor de fray Bernardino de Sahagún consistió en recuperar, hasta donde le fue posible, la cosmovisión compleja que se transmitía mediante imágenes asociadas a discursos memorizados y a veces cantados. Entrevistó a varios tlamatinime, o sea, los ancianos sabios, los filósofos e historiadores de ese mundo, durante más de dos décadas. Pudo hacerlo con éxito porque fue ayudado por un grupo de jóvenes pertenecientes a la nobleza mexica, acolhúa y tlaxcalteca, alumnos del Colegio de Santa Cruz de Tlaltelolco, quienes

\footnotetext{
2

Los chaneques no siempre se mencionan en relación con el culto a Tláloc; sin embargo, su descripción es similar a la de los ahuaques.

3 Sobre los sistemas de escritura náhuatl véanse, por ejemplo, Dibble (1971); Galarza (1979) y Lockhart (1999: 469-530).
} 
asumieron el papel de tlahcuiloque o pintores y escribas. ${ }^{4}$ Ellos pintaban las imágenes que expresaban la historia, los mitos y las categorías cognitivas y morales, y también describían las instituciones y prácticas sociales, económicas, políticas y religiosas del mundo nahua. A la vez, los tlahcuiloque transliteraban en alfabeto latino los textos en náhuatl con los significados de las pinturas. De este modo, se reunió un corpus riquísimo que hoy podemos encontrar —en parte- en los Códices matritenses. Luego, a partir de su procesamiento y estructuración, Sahagún y sus asistentes elaboraron, en 1579, el Códice florentino, integrado por 12 libros, con imágenes y textos en nahua y castellano. Por último, el fraile redactó en castellano, en 1585, la síntesis que tituló Historia general de las cosas de la Nueva España, también dividido en 12 libros. Así, la maravillosa herencia que ha llegado hasta nosotros consta de tres conjuntos interdependientes de textos e imágenes. Como reitera Magaloni Kerpel, se han realizado numerosos estudios sobre los textos escritos de la obra de Sahagún, castellanos y nahuas, aunque estos últimos no han sido traducidos en su totalidad, pero queda mucho por explorar en las pinturas y ella ha emprendido la tarea de investigarlas de manera exhaustiva.

Albores de la Conquista es una investigación fruto de dos premisas interesantísimas y exigentísimas. La primera es que las imágenes del corpus sahaguniano no pueden interpretarse sin el conocimiento de otros códices producidos por otros tlahcuiloque ni de las historias y crónicas escritas por misioneros, funcionarios, estudiosos españoles e intelectuales indígenas y mestizos. La segunda premisa es que las pinturas del Códice florentino fueron elaboradas por jóvenes intelectuales que no sólo conocían bien el mundo nahua al que pertenecían, sino que formaban parte también del mundo cristiano, occidental y mediterráneo, pues habían recibido en el colegio franciscano una educación esmerada en las lenguas castellana y latina, en filosofía y teología. Además, habían leído autores de la antigüedad clásica y conocido reproducciones de arte medieval y renacentista, por lo tanto, sus pinturas reflejan una combinación de ambas cosmovisiones. Es decir, al igual que los murales y decoraciones de las iglesias en las que intervinieron artistas indígenas, las pinturas deben considerarse ejemplares de una nueva plástica, un nuevo discurso visual que ha sido llamado arte indoamericano o tequitqui. ${ }^{5}$ Magaloni Kerpel emprendió el estudio de las imágenes del Libro XII del Códice florentino, en el que se narra la historia de la conquista de México-Tenochtitlan, desde el punto de vista de los nahuas. ${ }^{6}$ Pero antes, en el primer tercio del libro, presenta con gran erudición y agudeza los elementos de la cosmovisión nahua que contextualizan esa historia. En concreto, comunica la concepción del tiempo cíclico en el que se ubican los mitos de la creación del mundo y el género humano, pues su tesis es que para los tlahcuiloque de Sahagún la caída de Tenochtitlan representa el final catastrófico del último ciclo, correspondiente al quinto sol, pero también el comienzo de una nueva era en la que culminarían tanto los augurios mesoamericanos como los cristianos, por ejemplo, las profecías milenaristas de Joaquín de Fiore. El frontispicio del Libro XII muestra los ocho acontecimientos aterradores interpretados por los sabios nahuas y el emperador Motecuhzoma como presagios de la destrucción de Tenochtitlan. En la original interpretación de Magaloni Kerpel, estos presagios articulan

4

Como afirma Peterson (1988: 285), es probable que estos jóvenes hubieran adquirido el aprendizaje especializado que requería "la honorable profesión de tlahcuilo" antes de ingresar al Colegio.

5 Sobre el carácter híbrido o "mestizo" de los prototipos visuales utilizados por los tlahcuilos coloniales, véanse Peterson (1988: 288-293); Gruzinski (2007). Magaloni Kerpel señala que los significados de las imágenes también son producto de una cosmovisión mestiza emergente.

6 Esta versión contrasta con la final de la Historia..., de 1585, en la que Sahagún adopta un punto de vista más favorable a Cortés y los conquistadores (Cline, 1988). 
la narración de la Conquista y corresponden a las ocho divisiones del tiempo cósmico nahua, visibles en la llamada Piedra del Sol, en el frontispicio del Códice Fejérváry-Mayer (Seler, 1901-1902) y otros códices. La caída de Tenochtitlan está prefigurada en el cosmos. En las pinturas por las que discurre la narración, la autora va desentrañando las alusiones a elementos análogos en los mitos mesoamericanos, pero también en las visiones cristianas sobre el mensaje del ángel del Apocalipsis, la destrucción de Jerusalén, el papel de la Providencia divina en la historia, los misterios de la Encarnación y la Pasión de Cristo y la inevitabilidad de su segunda venida. La emigración de Aztlán y el abandono de TollanTeotihuacan encuentran paralelos en la expulsión del Edén o en el éxodo de Egipto. La artera captura de Motecuhzoma es análoga a la traición de Judas y su muerte evoca el ocaso de Quetzalcóatl. El lector puede entender y disfrutar los argumentos gracias a las 87 ilustraciones y docenas de viñetas, reproducidas con el cuidado que caracteriza las ediciones de Artes de México, aunque se echa de menos un glosario de los términos nahuas.

Concluyo. Me es imposible resumir en unos cuantos párrafos la riqueza y profundidad de Albores de la Conquista, pero quiero coincidir con quienes afirman que los dos autores cumbre en la literatura del Renacimiento mediterráneo son Miguel de Cervantes y Bernardino de Sahagún. Ambos escriben desde las márgenes de su civilización, cuando ésta dialoga con cosmovisiones que la enriquecen y la confrontan. De ese diálogo, que continúa en el México actual, Diana Magaloni Kerpel nos ha regalado un análisis espléndido. D

\section{Bibliografía}

Cline, Sarah L., 1988, "Revisionist Conquest History: Sahagún Revised Book XIl”, en J. Jorge Klor de Alba, Henry B. Nicholson y Eloise Quiñones Keber (eds.), The Work of Bernardino de Sahagún. Pioneer Ethnographer of Sixteenth-Century Aztec Mexico, The State University of New York-Institute of Mesoamerican Studies, Albany, pp. 123-152.

Dibble, Charles E., 1971, "Writing in Central Mexico”, en Gordon Ekholm e Ignacio Bernal (eds.), Handbook of Middle American Indians, vol. X: Archeology of Northern Mesoamerica, parte I, University of Texas Press, Austin, pp. 322-332.

Galarza, Joaquín, 1979, Estudios de escritura indígena tradicional azteca-náhuatl, Archivo General de la Nación/Centro de Investigaciones Superiores del Instituto Nacional de Antropología e Historia, México.

Gruzinski, Serge, 2007, El pensamiento mestizo. Cultura amerindia y civilización del Renacimiento, Paidós, Barcelona, Buenos Aires y México. Lockhart, James, 1999, Los nahuas después de la Conquista. Historia social y cultural de los indios de México central, del siglo xVI al XVIII, Fondo de Cultura Económica, México.

Lorente Fernández, David, 2006, "Infancia nahua y transmisión de la cosmovisión: los ahuaques o espíritus pluviales en la Sierra de Texcoco (México)", en Boletín de Antropología Universidad de Antioquia, vol. 20, núm. 37, pp. 152-168.

Peña, Guillermo de la, 1980, Herederos de promesas. Agricultura, política y ritual en los Altos de Jalisco, Centro de Investigaciones Superiores del Instituto Nacional de Antropología e Historia, México.

— 2006, Culturas indígenas de Jalisco, Secretaría de Cultura del Estado de Jalisco, Guadalajara.

Peterson, Janet Favrot, 1988, "The Florentine Codex Imagery and the Colonial Tlacuilo", en J. Jorge Klor de Alba, Henry B. Nicholson y Eloise Quiñones Keber (eds.), The Work of Bernardino de Sahagún. Pioneer Ethnographer of Sixteenth-Century Aztec Mexico, The State University of New York-Institute of Mesoamerican Studies, Albany, pp. 283-299.

Robertson, Margarita, 2002, Nos cortaron las ramas pero nos dejaron la raíz, tesis de maestría en estudios de la región, El Colegio de Jalisco, Zapopan.

Rojas Rabiela, Teresa, 1973, “La cerámica contemporánea de Tlayacapan, Morelos, México”, en Anales de Antropología, vol. 10, pp. $241-264$.

Sahagún, Bernardino de, 1975 [1585], Historia general de las cosas de la Nueva España, Porrúa, México.

Schwaller, John Frederick, 2014, "The Brothers Fernando de Alva Ixtlixóchitl y Bartolomé de Alva”, en Gabriela Ramos y Yanna Yannakakis (eds.), Indigenous Intellectuals. Knowledge, Power and Colonial Culture in Mexico and the Andes, Duke University Press, Durham y Londres, pp. $39-59$.

Seler, Eduard (ed.), 1901-1902, The Codex Fejérváry-Mayer. An Old Mexican Picture Manuscript in the Liverpool Free Public Museums, T. and A. Constable-Edinburgh University Press, Berlín y Londres. 